\title{
CONCEPTUAL INTEGRATIONS IN $L A$ PROSE DU TRANSSIBÉRIEN ET DE LA PETITE JEANNE DE FRANCE BY BLAISE CENDRARS
}

\author{
Craig Hamilton, University of Haute Alsace, Mulhouse, France \\ Email: craig.hamilton@uha.fr
}

In Memory of Gilles Fauconnier (1944-2021)

Received: June 19, 2021

Accepted: July 27, 2021

\begin{abstract}
In this paper, I discuss La Prose du Transsibérien et de la petite Jeanne de France by Blaise Cendrars, a narrative poem first published in French in Paris in 1913. The poem has raised seemingly intractable questions for many years, given its status as one of the most important modernist poems, and one of the most important poems in $20^{\text {th }}$ century French poetry. As I argue, considering some of the issues from the perspective of cognitive stylistics, especially the theory of conceptual integration, may help explain how readers make sense of this complicated poem.
\end{abstract}

Keywords: Blaise Cendrars, Cognitive Stylistics, Cognitive Linguistics, Conceptual Blending.

Resumen: En el presente artículo, analizo La Prose du Transsibérien et de la petite Jeanne de France, de Blaise Cendrars, un poema narrativo publicado por primera vez en francés en 1913. El poema ha suscitado cuestiones supuestamente inextricables durante muchos años, dada su categoría como uno de los más importantes poemas modernistas, y uno de los más importantes de la poesía francesa del siglo XX. Según argumento, considerar algunos de los temas tratados desde la perspectiva de la estilística cognitiva, especialmente la teoría de la integración conceptual, puede ayudar a explicar la manera en que los lectores encuentran el sentido de este complicado poema.

Palabras clave: Blaise Cendrars, Estilística Cognitiva, Lingüística Cognitiva, Combinación Conceptual, o Blending.

\section{INTRODUCTION}

In his essay "Breech and Convergence," the Nobel laureate Octavio Paz argued that modern poetry developed in three broad stages. The first stage began with Romanticism 
in the late $18^{\text {th }}$ century, and ended with Symbolism in the late $19^{\text {th }}$ century. According to Paz, "The history of modern poetry, from Romanticism to Symbolism, is the history of the various manifestations of the two principles that have constituted [modern poetry]... since its birth: analogy and irony" (1991: 38). Next, the early decades of the $20^{\text {th }}$ century saw what Paz calls modern poetry's second stage of development. Sandwiched, as it were, between Symbolism and Surrealism, Avant Garde poetry was written by poets who were fascinated with technology, and by the modern "city of crowds, brightly lit advertisements, streetcars, and automobiles, a city that every night transformed itself into an electric garden" (Paz 1991: 43). It is within this rich urban context that modernist poetry emerged. Since the 1940s, Paz argues, a modern "poetry of convergence" (1991: 53) has marked the third stage of development; poetry in this period seems more concerned with the immediate present than with either the past or the future.

In this paper, I focus on an example from the second stage, in the early $20^{\text {th }}$ century. According to Paz, between 1910 and 1920 "there appeared in painting, poetry, and the novel an art of temporal and spatial conjunctions that both dissolved and juxtaposed the dichotomies of before and after, front and back, internal and external. This art had many names; the best of them, the most descriptive, was Simultaneism" (1991: 48). Arguably, the most well-known literary text of this type is La Prose du Transsibérien et de la petite Jeanne de France by Blaise Cendrars, published in 1913. I focus on this poem in this paper because cognitive stylistics in general, and the theory of conceptual integration in particular (Fauconnier and Turner 2002), may offer answers to issues critics have had with this poem.

\section{ISSUES}

La Prose du Transsibérien et de la petite Jeanne de France by Blaise Cendrars is an unusual work of modern art that has posed many problems in literary criticism for many years. First, the poem's genesis is complex. Cendrars (1887-1961) was from the Frenchspeaking part of Switzerland, but lived in St. Petersburg, Russia, approximately between the ages of 15 and 19, where he worked, travelled, and learned Russian. At age 23, he travelled to New York in 1911, stayed again in Russia for a while, and then moved to Paris in 1912 (Perloff 2020: 224). Apparently, his poem "was written between December 1912 and June 1913" (Bochner 1978: 47-44), and first published in text form soon afterwards in summer 1913. In 1919, it was the central part of the published volume Cendrars called Du monde entier, which contained three long poems: Les Pâques à New York from 1912, La Prose du Transsibérien et de la petite Jeanne de France from 1913, et Le Panama ou les Aventures de mes sept oncles from 1914 (Cendrars 15-68). His 1913 poem is arguably one of the most important $20^{\text {th }}$ century French poems.

When Cendrars moved to Paris, he became close friends with many painters, including Fernand Léger, Picasso, Chagall, and especially Robert and Sonia Delaunay - Robert Delaunay's Russian wife (Bonord 2010: 11-14). Robert Delaunay's famous series of paintings of the Eiffel Tower at the time were examples of his efforts to put simultaneism into practice. Robert Delaunay was profoundly inspired by a book written in 1839 by Michel Eugène Chevreul, an industrialist, called De la loi du contraste simultané des couleurs (Peyré 2007: 86). In a rather scientific way, Chevreul emphasized the effects that contrasts 
in colors had upon our visual perception, making us see them differently in juxtaposition than we did in isolation. This perceptual effect of juxtaposition was called simultané, a term which Delaunay recycled for his artwork.

This leads to the second issue about the poem; its production as a visual work of art. When Cendrars wrote the poem in 1913, he was a frequent visitor in Delaunay's studio (Bochner 1978: 47-44). After he finished it, Sonia Delaunay worked with him to create a so-called livre simultané - or simultaneous book - with her painting inspired by the poem running down the left half of the page, and his poem running down the right half of the page (Robertson 1995: 891). The work was produced by hand on paper that was 2 meters long and roughly $36 \mathrm{~cm}$ wide, unfolding into 22 attached panels containing the nearly 500 lines and 40 stanzas of the narrative poem (Peyré 2007: 79). Although Paz called it "the first marriage between poetry and film" (1991: 45), the Delaunay-Cendrars work actually blends painting and poetry. The pair intended to print 150 editions of the work so that, when unfolded and lined up, they would be as tall as the Eiffel Tower itself; however, only 62 editions were ultimately printed (Rendell 1983: 36), despite intense advertising for placing orders. Only a few remaining examples are on public display today. That said, Cendrars' collaboration with Sonia Delaunay was rather fortuitous. According to Clare Rendell, Robert and Sonia Delaunay felt that " $[\mathrm{t}]$ he effect of contrasting colors could be compared with the activity of the mind because they give an impression of ceaseless movement. The Delaunays described this method of expressing the consciousness through color rhythms as simultaneity" (1983: 36). However, although the painters could contrast colors, or juxtapose them, and hope to represent mental movements in their paintings, the task of producing this effect with words was harder for Cendrars, a poet.

A third issue has been trying to read the visual artwork. According to Marjorie Perloff, “ $L$ a Prose is a 'simultaneous' artwork in that, seen on a wall, as it usually is today, rather than as the small accordion book, the viewer-reader does take in text and image simultaneously" (223). Yet, as Perloff also asks, "can one really absorb Cendrars' poem, with its almost 500 lines, in one glance?" (2020: 220-221). If simultaneism is understood as juxtaposition, then the poem and painting are clearly juxtaposed. Indeed, there is a stark contrast between Sonia Delaunay's bright and positive colors with the increasingly violent and negative tone of the poem by Cendrars (Perloff 2020: 230). But the sequential process of reading words prevents the poet from writing a text where all its lines are read simultaneously, at the same time, by one reader. While Perloff says that "the poem itself avoids linearity, cutting back and forth between different time frames and breaking spatial boundaries, as to emphasize a continuous present" (223), the actual cognitive process of reading the poem - in any format - is a linear process. What is more, this linear process of reading prevents the reader or viewer from reading the text and looking at the painting simultaneously. Our eyes can either focus on the poem, or on the painting, but not on both at the very same time (Shingler 2012: 6). The limitations of human vision mean that while we may see a painting all at once, like a Gestalt, it takes more time to read the text and discover its contents.

In addition, it is impractical to read the long poem on a wall when the work is 2 meters in height, and also when the ten font types, sizes, and colors used by Cendrars change so often (Bochner 1978: 98). The folded booklet, as it was printed in 1913, may make it physically easier to read the poem, but not see the painting in its entirety. When critics 
like Peyré praise the painted poem as a perfect illustration of simultanéisme (2007: 87), others like Paz emphasize the distinctiveness of the poem and the painting, and insist that the two cannot be "read" at the same time, despite their alleged simultanéisme. Indeed, as Christopher Butler implies, the painted poem may represent simultaneity, but the poem itself may not (1994: 161-162). Granted, no cognitive neuroscience experiments have apparently been carried out to see how readers really read this visual artwork, but given what we know about reading (Dehaene 2009), it seems reasonable to assume that readers actually interact with the painting and poem differently, even when they occupy the same page or space, as it were.

A fourth issue has involved categorization, for the work defies well-established genres. For instance, Robertson mentions the "difficulty of categorizing this work" (1995: 891). Today, textbooks in France tend to treat Cendrars as an Avant Garde poet (Mitterand 1994: 90). This is because, starting with La Prose du Transsibérien et de la petite Jeanne de France, Cendrars wanted to liberate poetry from its generic constraints. He thus chose the word "prose" for the title as he felt it to be more open and less constraining than "poem" (Bochner 1978: 102). After the poem was published in visual form in September 1913, "It was widely attacked in the press" and "a polemic around the seven-foot sheet with parallel text and abstract painting ... developed" in various literary reviews (Bochner 1978: 51). It is neither a painting, nor a poem, but rather both. It is not a written work of ekphrasis, since the painting did not inspire the poem. But neither is it a painted version of the poem, a kind of reverse ekphrasis. According to Jay Bochner, "Mme Delaunay's painting is definitively meant ... not to be an illustration. The poem and painting are one, and not a pictorial collage, since the words are of equal importance and must be read" (1978: 98). In ekphrasis, words are the servants of images, but in literary illustrations, images are put into the service of words. Yet as Bochner explains (1978: 102), neither ekphrasis nor illustration define the Delaunay-Cendrars work.

As we can see, many critics in the past have discussed and debated the poem's genesis, its status as a verbal or visual work of art, and the challenges it poses for readers trying to read it. The literary history of modernism may answer questions about the poem's genesis, Cendrars' sources of inspiration, and how or why Sonia Delaunay and Cendrars created their work of art. Genres in literature in general, and in poetry in particular, relate to categorization theory (Hamilton 2013). What I call Cendrars's narrative poem may thus be discussed in the context of cognitive science research into categorization.

However, questions about reading the poem itself may be best addressed through cognitive stylistics. Stylistics is often about unpacking causal relations, seeing how a certain feature of style in a text produces a specific effect upon a reader. The focus of cognitive stylistics is a little different. According to Paul Simpson, it focuses on "the cognitive structures that readers employ when reading texts" as well as on "the process of reading" (2004: 39). More recently, David West (2011: 250) has stated that cognitive stylistics may "make conscious and visible through its dealings with literature those cognitive processes which are unconscious and invisible." As I discuss below, the theory of conceptual integration from cognitive linguistics may help us understand how readers make sense of the poem Cendrars wrote in 1913, before his collaboration with Sonia Delaunay. 


\section{THE 1913 POEM}

The written poem most readers are familiar with is almost 500 lines long and contains about forty stanzas (Cendrars 2004: 27-45). In the poem, the persona is a young man who travels on the famous Trans-Siberian train, from Moscow, Russia to Harbin, China, in the first decade of the $20^{\text {th }}$ century. The train departs on a Friday morning in December, packed with merchants and others seeking to make their fortune in the East. For Bochner, "The train represents the terrible flight of a boy of sixteen who wants so much of the world and life that he is on the verge of breaking everything about him" (1978: 103). On the train, there is a man who has a hundred boxes of alarms and cuckoo clocks from the Black Forest in Germany. Another has hat boxes, cylinders, and cork screws from Sheffield. Still another has coffins from Malmo, Sweden, filled with tin cans and sardines in oil. The speaker, who works for a man who has 34 boxes of cheap German jewelry to sell, carries a small Browning pistol with him to protect the jewelry. There are also prostitutes on the train who run a profitable business. Among them, presumably, is the "petite Jeanne," the young prostitute the speaker falls in love with on the journey, and to whom he speaks dreamily about distant lands. Jeanne refers to the poet by his first name (Blaise) by asking him the same question six times at different points in the poem - "Dis, Blaise, sommes-nous bien loin de Montmartre?" [Say, Blaise, are we really far from Montmartre?]. This suggests that the poem is autobiographical in parts, although it is also ironic, as Blaise Cendrars was the pen name of Freddy Sauser.

As the train heads east, the persona - Blaise - goes through many towns and regions: Tomsk, Tcheliabinsk, Kainsk, Obi, Ufa, Taichet, Verkne, Oudinsk, Kourgane, Samara, Pensa-Toulane, Irkoutsk, Lake Baykal, Talga, Khilok, Krasnoyarsk, Tchita, Mongolia, the Gobi Desert, Khailar, Tsitska, and Harbin in China. As the train heads east, the tone becomes more pessimistic. According to Perloff (2020: 229), this stanza near the end is "the turning point of the poem," as Jeanne is no longer mentioned, and dark or violent images dominate the poem:

J'ai vu

J'ai vu les train silencieux les trains noirs qui revenaient de l'Extrême-Orient et qui passaient en fantôme

Et mon oeil, comme le fanal d'arrière, court encore derrière ses trains

A Talga 100000 blessés agonisaient faute de soins

J'ai visité les hôpitaux de Krasnoïarsk

Et à Khilok nous avons croisé un long convoi de soldats fous

J'ai vu dans les lazarets les plaies béantes les blessures qui saignaient à pleines orgues

Et les membres amputés dansaient autour ou s'envolaient dans l'air rauque

L'incendie était sur toutes les faces dans tous les cœurs

Des doigts idiots tambourinaient sur toutes les vitres

Et sous la pression de la peur les regards crevaient comme des abcès

Dans toutes les gares on brûlait tous les wagons

Et j'ai vu

J'ai vu des trains de soixante locomotives qui s'enfuyaient à toute vapeur pourchassés par les horizons en rut et des bandes de corbeaux qui s'envolaient désespérément après

Disparaître 
Dans la direction de Port-Arthur (Cendrars 2004: 42-43).

[I saw

I saw the silent trains the black trains returning from the Far East and going by like phantoms And my eyes, like tail lights, are still trailing along behind those trains

At Talga 100,000 wounded were dying with no help coming

I went to the hospitals in Krasnoyarsk

And at Khilok we met a convoy of soldiers gone insane

I saw in quarantine gaping sores and wounds with blood gushing out

And the amputated limbs danced around or flew up in the raw air

Fire was in their faces and in their hearts

Idiot fingers drumming on all the windowpanes

And under the pressure of fear an expression would burst like an abscess

In all the stations they had set fire to all the cars

And I saw

I saw trains with 60 locomotives streaking away chased by hot horizons and

Desperate crows

Disappearing

In the direction of Port Arthur.] (Perloff 2020: 228-229).

The persona sees human misery on massive scale: soldiers maimed or wounded in the Russian-Japanese War (1904-1905) are heading west, others have gone insane, buildings and carriages are burning, while in between towns there are seemingly endless or desolate plains. The scene above ends with an allusion to the Russian defeat at Port Arthur. As for the style in lines like those above, according to Robertson, their "fragmented syntax ... jettisons all extraneous verbs and conjunctions in order to minimize the conceptual gap between experience and its narration" (1995: 892). Here, and elsewhere, Cendrars uses a catalogue technique - listing items in rapid fashion - usually to represent images as they pass the poet by in the train's window. The effect is what William Dow (1996: 400) calls a "simultaneous flocking of images," a point we will return to later on. In sum, the written poem was an experiment in free verse that was new for Cendrars, new for French poetry at the time, and is perhaps why many readers find it a challenge to read or fully understand. This is where cognitive stylistics might be of help.

\section{PROMINENT CONCEPTUAL BLENDS IN THE POEM}

Readers of the written poem engage with various conceptual blends, and the most prominent ones merit some discussion here. First, there is its genre. For Robertson (1995: 891), "the poem refers implicitly to an age-old heritage of oral narrative in its epic length and even its title": La Prose du Transsibérien et de la petite Jeanne de France. Cendrars situates the poem in a literary tradition of epic poems, or travel narratives, and the word "prose" in the title invites us to see the free verse poem as a narrative. While the painted version that Cendrars made with Sonia Delaunay blends literature with painting, the verbal poem itself already combines elements of poetry - free verse - with elements of prose narration - intertwined stories. It is for this reason that I call the text a narrative poem, rather than a prose poem or a verse novel, which it certainly is not. In other words, even 
in its common written form, the poem is a blend of genres, creating in the process an epic modernist poem before Ezra Pound's "Hugh Selwyn Mauberley" (1920) or T.S. Eliot's "The Waste Land" (1922).

Second, critics have called the train journey in the poem a "metaphor" (Robertson 1995: 892) or "métaphorique" (Le Quellec Cottier 2013: 12). Indeed, the long poem combines at least two stories at once. There is the coming-of-age story of the young poet who travels far from home as adolescence gives way to adulthood. As Cendrars repeats several times near the start of the poem - “... j'étais fort mauvais poète. / Je ne savais pas aller jusqu-au bout." [I was a really bad poet. / I did know how to go all the way.] Then there is the love story - boy meets girl, boy loses girl - between "Blaise" the persona and little "Jeanne," a French prostitute. Cendrars thus blends two well-known conceptual metaphors - LIFE IS A JOURNEY and LOVE IS A JOURNEY - in his story. The train journey begins in Moscow, perhaps in 1904, but in 1913 "the poem ends in Paris, the train gone with youth" (Bochner 1978: 103).

Regarding this blend, it is worth noting that the Trans-Siberian train journey, nearly 10,000 kilometers from end to end, used to take forty-five days. According to Bochner (1978: 104), Cendrars' "train ride of a few weeks compresses years of ageing," and everything the persona experiences in the poem occurs within a time frame of roughly six weeks. Compression is one of the most important features in conceptual integrations (Fauconnier and Turner 2002), and comments by critics which recognize temporal compression in the poem point to this blend's vivid reality.

Indeed, some readers have noticed this blend before, without understanding that conceptual integration is the process involved with reaching this interpretation. According to Bochner, the poem is like a quest, "concerned with travelling through the modern, this time physically, devastated world and searching out one's frail identity in terms of that disintegrating world" (1978: 97). For this reason, Bochner sees this as a coming of age poem: the poet travels 'from' youth 'to' adulthood by travelling east across Eurasia, before finally ending up in Paris as an adult nearly ten years later. As Bochner puts it (1978: 104), "along with a train ride through Russia, there is a trip through time from faraway adolescence in Moscow to manhood in Paris." This remark reveals the successful integration of LIFE IS A JOURNEY and LOVE IS A JOURNEY. For Perloff (2020: 231), the poem's "narrative is pretty straightforward. It begins ... when the poet is a carefree adolescent in Moscow and takes him, via the train journey, to a maturity no longer so insouciant or fun-loving." These are signs that the poem by Cendrars is understood on one level as a coming-of-age narrative, as the protagonist moves through space physically in order to mature psychologically. Such a blend that is not uncommon in literature, including highly creative modernist literature (Hamilton 2004). Moreover, what makes these inputs effective is their shared origin in the source-path-goal image schema, and their manifestations as instances of the more schematic Location Event Structure Metaphor (Dancygier and Sweetser 2014: 45).

The third blend of note is that of the poet's personal story with early $20^{\text {th }}$ century world history. Cendrars could have chosen to write a poem about lost love, a poem about a poet growing up, a poem about travel, or a poem about world events; instead, he chose to do all these things in one poem. As Małgorzata Zawadzka claims, the poem represents a real train journey, a poetic exposé, and also an imaginary journey through time and space (2007: 
47-50). Indeed, Cendrars' narrative poem is full of references or allusions to many different places. For instance, he mentions over thirty locations, including the ancient city of Ephesus, Sheffield, Malmo, Pforzheim, Golkonda (in India), Novgorod, Flanders, Scotland, Babylon, Basel, Timbuktu, New York, Madrid, Stockholm, Patagonia, Fiji, the Phoenix Islands, the Marquesas Islands, Borneo, Java, Japan, Mexico, Peru, Berlin, St. Petersburg, Grodno (in Poland), Bruges, Venice, Prague, France, Italy, America, and, finally, Paris. Likewise, Cendrars refers to many different events, centuries apart in time. For example, he refers to the legend of the founding of Novgorod (late $10^{\text {th }}$ century), the death of Archimedes at Syracuse (circa 212 BC), the Boxer Movement in China (circa 1900), the Aztec Empire (which peaked before the $16^{\text {th }}$ century), the sinking of the Titanic (1912), the RussianJapanese War (1904-05), airplanes, and even prehistoric mammoths. Last, but not least, Cendrars also refers (or alludes) to Christ, the coming Russian Revolution, and many late $19^{\text {th }}$ century or early $20^{\text {th }}$ century artists, such as Hugo Wolf, Mussorgsky, Maeterlinck, Henri Rousseau, Marc Chagall, Apollinaire, Jules Verne, and even Alexei Kuropatkin, the Russian Minister for War during the Russian-Japanese War.

Clearly, the poem is crowded with an incredible number of people, places, and events. These "dislocations and time shifts" (Perloff 2020: 231) coincide within a single poetic narrative, apparent signs of the poem's alleged simultaneity. Yet that term's explanatory power has diminished due to all the contradictory definitions of it used before (Demougin 1986: 1527; Rey and Rey-Debove 1989: 1817; and Dow 1996: 400). Cendrars himself never clearly explained what that term meant. He once claimed that his poem was full of "contrastes simultanés" (qtd. in Bochner 1978: 98), but then later wrote, "Le simultané est une technique. La technique travaille la matière première, matière universelle, le monde. La poésie est l'esprit de cette matière" ["The simultaneous is a technique. The technique works on raw material, a universal material, which is to say the world. Poetry is the spirit of this material"] (qtd. in Dow 1996: 399). While Einstein and Bergson were also struggling with the new space-time conceptual integration in physics at roughly the same time (Evans 2003: 243-247), it is clear that painters like the Delaunays had in mind Chevreul's specific definition of simultaneity when it comes to painting. But the term's polysemy in literary criticism has been the source of much confusion.

No matter what we name it, this third blend seems to be a SPECIFIC IS GENERIC integration. As Robertson notes (1995: 891), "the poem fuses the everyday with the esoteric, alternating images of childhood innocence and exuberance with those of corruption, violence, and despair." The fusion Robertson mentions here is evidence that Cendrars is blending stories, including world history with the poet's personal history. Historical events and physical locations familiar to the poet provide a backdrop to understand his specific and singular life. The impact Cendrars had on those who met him in 1912 cannot be underestimated. As the French writer Paul Morand said, when Cendrars moved to Paris at the age of 24, he had already seen everything - "Cendrars ... avait déjà tout vu ..." (qtd. in Cendrars 2004: 9). While Cendrars had not travelled by then to all the places he mentions, nor lived through all the epochs alluded to, of course, his blend of the generic with the specific, or the global with the local, shows that his singular text emerges from the dramatic context of world history. Cendrars writes about a personal journey on one Trans-Siberian train, a train scheduled to leave Moscow every single Friday morning (2004: 29-30). He 
also states, "Et cette nuit est pareille à cent mille autres quand un train file dans la nuit" (2004: 33) [And this night is like a hundred thousand others when a train runs through the night]. In fact, his specific train is but one of a generic series of trains - the Trans-Siberian - a conceptualization known as identification, which is important in conceptual blending theory (Fauconnier and Turner 2002), especially in SPECIFIC IS GENERIC blends.

The fourth and final blend I will discuss here relates to stylistics and embodied cognition. In my Gallimard edition in French, the full poem spans eighteen pages (Cendrars 2004: 27 45), and it privileges the linguistic code rather than the bibliographic code (McGann 1991), since the typography of the painted poem is not mimicked in the printed poem that most readers are familiar with. The narrative poem is almost entirely written in free verse; there are nearly 500 lines in roughly forty stanzas, and five quatrains, written roughly in alexandrines, comprise the only formal part of the poem really, a brief sign of order that interrupts the poem's apparent disorder (Peyré 2007: 89). Lines vary in length, from as few as one word and two syllables, to up to twenty-eight words and forty-seven syllables. Stanzas also vary in size, from just one line, to as many as thirty lines of verse (or more). In his study of the poem, Clive Scott (1993: 57) suggests Cendrars was trying out a new technique focused on accents per measure more akin to music, rather than use conventional techniques for writing French verse. Also, the poem's lack of standard punctuation was new for Cendrars, and influenced Apollinaire's Alcools, while the poem's modernist, "fragmented, telegraphic style" was allegedly inspired by the painter Robert Delaunay (Robertson 1995: 882-883).

Many critics thus comment on Cendrars' unusual style, but they also see it as mimetic of movement on a train (Giraud 2013: 493). For instance, Robertson (1995: 892) calls the train journey "a metaphor of the poet's tortuous search for a new creative medium," while Peyré (2007: 83) speaks of a correspondence between the text and "un ensemble de perceptions." Meanwhile, Perloff (2020: 225) sees Cendrars" "loose paratactic free verse strophes ... [as] reminiscent of [Walt] Whitman," and later concludes that the "rhythm of that narrative ... is designed to capture the motion of the moving train" (2020: 226). Such remarks about this poem are quite common, and they reveal a FORM IS CONTENT blend. The unconventional free verse form that Cendrars experiments with is seen as inspired by, or as representational of, modern train travel. Form becomes content. Ironically, Cendrars refers to time a lot in the poem, to clocks and watches, and even to the timing of train engines, saying at one point that European engines fire four times when moving, while Asian ones five or seven times (2004: 43).

As the entire trip eastward in the early $20^{\text {th }}$ century took Cendrars about six weeks, compared to about ten days now, our own experience of rather smooth and regular train travel was not exactly the experience Cendrars had. The poem records frequent stops and starts, changes of speed, and alternations between idle periods in stations, short excursions, and then stretches of travel at breakneck speed. This pattern might explain the poem's highly irregular style, which lines like these reveal:

Je suis en route.

J'ai toujours été en route

Je suis en route avec la petite Jehanne de France

Le train fait un saut périlleux et retombe sur toutes ses roues

Le train retombe sur ses roues

Odisea, $n^{\circ} 22$, ISSN 1578-3820, 2021, 23-27 
Le train retombe toujours sur toutes ses roues (Cendrars 2004: 33-34).

[I am on the road.

I am always on the road

I am on the road with little Jeanne of France

The train makes a perilous jump and falls back onto its wheels

The trains falls back onto its wheels

The train always falls back onto all of its wheels]

The two ways to produce foregrounding in a literary text are by deviation from an external or internal norm, or by repetition - giving readers what is predictable, or simply more of the same (Simpson 2004: 50). On the one hand, Cendrars' experiment in free verse deviates from the traditional conventions of French poetry; it is thus natural for his style to attract the attention of critics. His grammar and register also shift remarkably in the poem, moving between almost formal or standard sentences to informal and ungrammatical lines. On the other hand, Cendrars uses repetitions, but in unpredictable ways. His stanzas are almost always unequal in size, and his lines are almost always unequal in length, with few signs of strict rhymes or metric feet. This naturally stands out for critics, and is thus foregrounded. It may be why the FORM IS CONTENT blend informs many critical discussions of this long, narrative poem.

Finally, while frequents shifts in verb tenses (past simple, past perfect, present, future, etc.) occur throughout, what holds it all together is that Cendrars "records the thoughts of a single speaker" more or less throughout the entire poem (Butler 1994: 159). As Perloff writes (2020: 223), "the poem ... avoids linearity, cutting back and forth between different time frames and breaking spatial boundaries, as to emphasize a continuous present." This is a feature Paz would associate with modern poetry after the 1940 s, yet critics agree that Cendrars used a verbal style that tried to mime the embodied experience of train travel. The uneven pace of his trip is shown by uneven lines of free verse. The disorder of world history reflects the disorder of the poet's gradual development. Simply put, the work is an example of what Joan Truckenbrod (1992: 95) called integrated creativity, an "artwork that mirrors the human experience by skillfully combining a variety of forms of artistic expression." Such interpretations about form mirroring content, or form mimicking content, arise from a FORM IS CONTENT blend, where irregular verse forms embody irregular narrative content and physical motion.

\section{CONCLUSIONS}

La Prose du Transsibérien et de la petite Jeanne de France by Blaise Cendrars is one of the most complex poems ever written during modernism. In its verbal and visual forms, it is hard to categorize, and highly unusual to read. Furthermore, the eternal confusion about what simultaneity means for a literary text has always complicated discussions of the poem (Robertson 1995: 891). While paintings by the Cubists or the Delaunays suggest that simultaneism is possible in painting, as Paz writes, "Poetry cannot be synchronous without going against its very nature and renouncing the great power of the word" (1991: 49). Despite all these problems, critics like Bochner (1978: 102), Butler (1994: 162), and 
Peyré (2007: 83) praise the work, while those like Perloff (2020: 231) openly wonder about all the problems it has posed for so many critics for so many years.

For my part, I have tried to show that reading this complex work entails a number of conceptual blends. Due to lack of space and time, not all of them could be discussed here, but I did address four main ones. First, the work can be called a NARRATIVE POEM for it blends elements of poetry with elements of fiction. Second, the work combines of a love story with the coming-of-age story, based on two conceptual metaphors becoming input spaces for the blend: LOVE IS A JOURNEY and LIFE IS A JOURNEY. Third, there is a combination of a personal history with world history, or what I have called a SPECIFIC IS GENERIC blend. Finally, there is the new free verse style used by Cendrars, yielding what I call a FORM IS CONTENT conceptual blend. When discussing each of these blends, I have turned to remarks published by critics for evidence which attests to the status of each blend. This overcomes what I call the ' $n=1$ ' problem - much work in stylistics describes one reader's experience with reading a text, even a famous poem like Cendrars', rather than see how other readers are able to make sense of the work.

Of course, more could be said about the compression of time and space in the poem, and about specific stylistic triggers for mental space builders, such as conditional forms, deictics, tenses, and semantic referents. These are fruitful avenues for future research. However, for the purposes of simplification, I have focused only briefly on the main inputs to the four main blends, and I have left out more technical details and diagrams. That said, I hope this paper adds to the cognitive stylistic literature on conceptual integration, and to the body of knowledge concerning Cendrars' landmark poem. I also hope that this paper offers some evidence for the integrated creativity that Truckenbrod uncovers in the poem. Such creativity occurs when "multiple modes of creative expression are combined" (Truckenbrod 1992: 89). All these combinations are keys to understanding La Prose du Transsibérien et de la petite Jeanne de France by Blaise Cendrars. ${ }^{1}$

\section{REFERENCES}

Bochner, J. 1978. Blaise Cendrars: Discovery and Re-Creation. University of Toronto Press.

Bonord, A. 2010 "Blaise Cendrars et les peintres: trois expositions." Feuille de routes, 48: 11-14. https://www.jstor.org/stable/45060071.

Butler, C. 1994. Early Modernism: Literature, Music and Painting in Europe, 1900-1916. Oxford University Press.

Cendrars, B. 2004 [1967]. Du Monde Entier: Poésies Complètes 1912-1924. Preface by Paul Morand. Paris: NRF Gallimard.

1 An earlier version of this paper was presented at the PALA conference in July 2009 at the University of Sheffield. I would like to thank colleagues there for initial feedback on the work, as well as anonymous peerreviewers for their comments on this version of the paper. This paper is dedicated to the late Gilles Fauconnier, a pioneer in cognitive linguistics who was originally from France. He helped me obtain a Chateaubriand Fellowship to the prestigious Ecole Polytechnique in Paris in 1999-2000 during the third year of my PhD program, while I was studying under the supervision of Mark Turner. Gilles could undoubtedly describe many more blends in the poem by Cendrars than I have discussed here. He will be sincerely missed. 
DAncygier, B. \& E. Sweetser. 2014. Figurative Language. Cambridge University Press.

Dehaene, S. 2009. Reading in the Brain: The New Science of How We Read. London: Penguin.

Demougin, J. 1986. Dictionnaire Historique, Thématique, et Technique des Littératures Française et Étrangères, Anciennes, et Modernes. Paris: Larousse.

Dow, W. 1996. “John Dos Passos, Blaise Cendrars, and the 'Other' Modernism.” Twentieth Century Literature, vol. , 43,3: 396-410. https://doi.org/10.2307/441770

Evans, V. 2003. The Structure of Time. Amsterdam: Benjamins.

Fauconnier, G. \& M.Turner. 2002. The Way We Think: Conceptual Blending and the Mind's Hidden Complexities. New York: Basic Books.

Giraud, M. 2013. "La Prose du Transsibérien et de la Petite Jehanne de France de Blaise Cendrars, ou les Sursauts de la Mémoire." Contemporary French and Francophone Studies, vol., 17,5: 493-501. https://doi.org/10.1080/17409292.2013.844483.

Hamilton, C. 2004. "Life is a Journey: The Course of a Conceptual Metaphor in The Voyage Out by Virginia Woolf.” Bulletin de la Société de Stylistique Anglaise 25: 125-140. [original paper published in French].

Hamilton, C. 2013. “Cognitive Categories and Literary Genres.” Presentation at the $1^{\text {st }}$ International Cognitive Poetics Conference. University of Osnabruck, Germany, 26 April.

Le Quellec Cottier, C. 2013. “ « Nos Yeux Vont Jusqu’au Soleil » : Blaise Cendrars, Sonia Delaunay et les Montres Zenith.” Continent Cendrars, 15: 11-16. https://www. jstor.org/stable/45057178.

McGann, J. 1991. The Textual Condition. Princeton University Press.

Mitterand, H. 1994. Littérature du XXe siècle: Textes et Documents. Paris: Nathan.

PAz, O. 1991. The Other Voice. Trans. Helen Lane. San Diego: Harcourt Brace.

Perloff, M. 2020. "How 'simultaneous' is it? Revisiting the Delaunay-Cendrars collaboration on La Prose du Transsibérien." 1913: The Year of French Modernism, Effie Rentzou and André Benhaïm Eds. Manchester, UK: Manchester University Press. 220-236. https://doi.org/10.7765/9781526145031.00023>.

Peyré, A. 2006-2007. "La simultanéïté dans "La Prose du Transsibérien et de la petite Jehanne de France" de Blaise Cendrars et Sonia Delaunay." Feuille de routes, 45/46: 79-88. https://www.jstor.org/stable/45060043.

Rendell, C. 1983. "Sonia Delaunay and the Expanding Definition of Art." Women's Art Journal 4.1: 35-38. http://www.jstor.org/stable/1358099.

Rey, A. \& J. Rey-Debove. 1989. Le Petit Robert Dictionnaire. Vol. 1. Paris: Robert.

Robertson, E. 1995. "Painting Windows: Robert Delaunay, Blaise Cendrars, and the Search for Simultaneity." The Modern Language Review, Vol. 90. 4, 883-896. https://www. jstor.org/stable/3733064. 
Scotт, C. 1993. Reading the Rhythm: The Poetics of French Free Verse, 1910-1930. Oxford: Clarendon Press. DOI:10.1093/acprof:oso/9780198158820.001.0001.

SHINGLER, K. 2012. "Visual-verbal encounters in Cendrars and Delaunay's La Prose du Transsibérien." e-France, 3:1, 1-28. http://www.reading.ac.uk/web/files/modernlanguages-and-european-studies/Katherine_Shingler_Visual_Encounters_in_Cendrars_ and_Delaunays.pdf.

Simpson, P. 2004. Stylistics: A Resource Book for Students. London: Routledge.

Truckenkrod, J. 1992. "Integrated Creativity: Transcending the Boundaries of Visual Art, Music, and Literature." Leonardo Music Journal, 2:1, 89-95. https://www.jstor. org/stable/i267383.

West, D. 2011. "Teaching Cognitive Stylistics.” Teaching Stylistics, eds. Lesley Jeffries and Dan McIntyre. Basingstoke: Palgrave Macmillan, 239-255.

ZAWADZKA, M. 2006-2007. "L'Imaginaire poétique de Blaise Cendrars." Feuille de routes, 45/46: 47-50. https://www.jstor.org/stable/45060039. 